\title{
SADC'S PURSUIT OF MARITIME SECURITY IN A REGION LACKING REGIONALISM
}

\author{
Timothy Walker \\ Maritime Project Leader and Senior Researcher \\ Institute for Security Studies
}

\begin{abstract}
Southern African Development Community (SADC) member states participate in many regional and multilateral initiatives that aim to enhance collective maritime security. How these initiatives affect state behaviour, and how African states' interests and values, in turn, shape the functioning of these initiatives remain underexplored in maritime security studies. In addition, the study investigated the significance of SADC-focused regionalism as a force for its member states as they develop and implement foreign policies concerning maritime security in the region.
\end{abstract}

\section{Introduction}

The study on which this article is based will explore the ways in which SADC member states collaborate in the pursuit of more effective maritime security in the Southern African region. Maritime security in the Southern African context is best understood as a 'wicked problem' for which regional initiatives can provide appropriate solutions for common security. Consensus on a maritime security definition has yet to be attained. ${ }^{1}$ Bueger characterises maritime security as a 'buzzword'; indeed, the concept is intersubjective. $^{2}$ The current study understood African maritime security as the prevention and absence of maritime crimes for African communities - both states and non-states - as well as the enabling of African communities to achieve greater levels of human security.

The majority of threats challenging African states' maritime security are 'traditional', as they are common threats to which most African navies and coastguards have routinely responded. ${ }^{3}$ The kinds of maritime crimes observable in the African maritime domain are becoming far more numerous, transnational, sophisticated and complex than in the past and they are interlinked intricately enough to mark them as presenting a complicated kind of security challenge. Bateman applied the useful concept of 'wicked problems' to these issues in Asia. ${ }^{4}$ Viewing maritime security issues as 'wicked problems' does not imply evilness but points to their complexity, comprising multiple dimensions and impacts, and the fact that they are not easily resolved by narrowly focusing on single problems and single solutions. Rather, 'wicked problems' are best tackled via multilateral security initiatives, such as regional forums, that are able to adopt comprehensive strategic approaches supported by collaborative or cooperative policies. Wambua made an early case for regional maritime cooperation as "perhaps the only avenue through which African states can achieve order in the governance of their ocean areas", because "the challenges of governing ocean spaces can be daunting if handled unilaterally". 5 
This article presents five significant empirical themes where the exhibition of regionalist behaviour by SADC member states could be observed and analysed. For the purposes of this article, the geographic area called the Southern African region will be understood as coterminous with the 16 SADC member states. Firstly, the article reflects the increasingly complex nature of the SADC's maritime political geography. Secondly, it reports on the SADC's historical and contemporary geopolitical significance to both member and external states. Thirdly, an evaluation of the agency and leadership demonstrated by SADC member states in regional and global maritime security initiatives and institutions is provided. Fourthly, the outcomes of the SADC Standing Maritime Committee's (SMC) annual meeting and, finally, the development, implementation and ongoing revision of the SADC Maritime Security Strategy (MSS) are presented.

At the time of writing, the confidential nature of the SADC MSS posed a substantial methodological obstacle. Public debate and scrutiny have also typically taken place without reference to the specifics of the MSS. These research difficulties were mitigated to some extent by the author's involvement in the revision of the SADC MSS in $2019 .{ }^{6}$

\section{SADC's maritime political geography}

Southern African states need to be cognisant of the region's increasingly complex maritime political geography. The $16 \mathrm{SADC}$ member states comprise over a quarter of all African states; 10 of the 16 member states are characterised as coastal or island. ${ }^{7}$ The four SADC island states are located in the Indian Ocean. ${ }^{8}$ The overlapping membership by SADC member states of various sub-regional and international organisations other than the SADC also means that what is considered SADC's maritime political geography is not wholly under the auspices of SADC regional maritime initiatives. The SADC is also unique among African regional economic communities (RECs) as the member states are pivotally located between the Atlantic and Indian Oceans. South Africa's sovereignty over the Prince Edward and Marion islands extends the SADC's presence and interests far into the Southern Ocean too.

The complexity of the SADC's maritime political geography is further increased when applying the African Union (AU) definition of the 'African maritime domain'. ${ }^{9}$ As per the 2050 Africa's Integrated Maritime Strategy (2050 AIMS), the significant lacustrine (lake) areas that form part of the territories of countries such as Malawi, Tanzania and the Democratic Republic of the Congo (DRC) should now also be considered. ${ }^{10}$ The SADC has been a notable pioneer of this approach long before the adoption of the 2050 AIMS in 2014, and SADC member states have organised multiple multilateral riverine and lacustrine exercises. ${ }^{11}$

Continental shelf claims could add yet further areas to SADC member state ocean considerations, and could be the source of disputation. ${ }^{12}$

Future management of disputes arising over the spatial locations of zones and boundaries within the SADC's maritime political geography will be best understood if viewed against the backdrop of the increasing territorialisation of the oceans. This is 
driven by advances in technology and demand for resources, such as oil, gas and minerals located in (often deep and distant) offshore areas. ${ }^{13}$ Sea-level rises are also posing an existential threat to some states and can complicate the demarcation of boundaries. ${ }^{14}$

Many SADC maritime boundaries could be disputed in future (while some have been resolved, there are many dormant or potential sites), such as between Angola and the DRC. ${ }^{15}$ Disputes could also arise over ownership of inland waterways and lakes. A long-standing dispute, for instance, persists between Malawi and Tanzania over the location of their border in relation to Lake Malawi. ${ }^{16}$

Finally, some SADC member states are disputing the sovereignty of external states over numerous islands located in the Mozambique Channel and further out into the Indian Ocean. ${ }^{17}$

\section{SADC's maritime geopolitical significance}

From a maritime perspective, geopolitical influences have a great impact on the policies and behaviour of Southern African states and states from outside of the region, some of them dating back centuries. ${ }^{18}$

The Southern African region has been the site of centuries-long competition between European mercantile powers, such as Portugal, the Netherlands and Britain. These countries and their representatives competed for centuries first to conquer and then to colonise the area in order to control the vitally important shipping route around the Cape of Good Hope that linked Europe and Asia. The Cold War contest between the United States of America (USA) and the Union of Soviet Socialist Republics (USSR) and debates over the security of Southern African resources and of the Cape shipping route were also major influences on geopolitically informed foreign policies during decolonisation and in the post-colonial period.

The relative value attached to the Southern African shipping route was permanently affected by the construction of the Suez Canal in the nineteenth century. The opening of the Suez Canal significantly reduced the geopolitical importance of controlling the area. Ships sailing between Europe and Asia could now take an alternative route that was (and remains) far shorter, cheaper and safer than the route around the Cape of Good Hope.

The economic rationale behind the choice to sail along either the Cape of Good Hope or the Suez Canal shipping route and the types of vessels used has been contingent upon the extent to which Suez remains both open and secure. For instance, the Cape route was the only viable route from 1956-1957 and then from 1967-1975 when the canal was closed both times as a result of war. The necessity of economically shipping oil from the Middle East to supply the oil-dependent economies of the United States, Europe and north-east Asia resulted in the creation of a new, larger types of 'Capesize' vessels. As these Capesize vessels were too large to use the Suez Canal after it was reopened in 1975 they continue to use the Cape route, although the expansion of the Suez Canal in 2015 does allow for the transit of some Capesize ships. 
The surge in Somali piracy from 2008-2011 elicited debates about whether the rerouting of shipping around the Cape instead of through Suez was a temporary or longer-term trend. A small number of vessels were re-routed around the Cape during the crisis, at the cost of additional time and revenue for the shipping companies involved. Most however chose to mitigate the risk of being hijacked by implementing best management practices while sailing through the piracy hotspots and the designated High Risk Area (HRA), including the considerable expense and controversy of employing armed guards on board. ${ }^{19}$ This indicated that there was a high tolerance of risk regarding the threat of Somali piracy, which meant that the perceived value of the alternative Cape route did not rise enough to see it continue as a major alternative shipping route to Suez in the medium to long term.

The other enduring and long-term influence on geopolitical interest in the region occurred upon the discovery of huge quantities of valuable natural resources, such as gold, platinum, diamonds, cobalt and manganese. It now appears to be occurring again with the (unexpected) discovery of huge gas fields in the exclusive economic zones (EEZs) of Tanzania and Mozambique in 2010.

Large multinational energy companies are the only actors with the capital and expertise for extracting these resources. ${ }^{20}$ Local actors or companies cannot viably extract these resources by themselves (South Africa's SASOL [South Africa Synthetic Oil Liquid] has done limited extraction in the past in Mozambique and offshore around South Africa). Many interested companies are state-owned or are strongly affiliated to the national interests of their countries of origin who are also are investing in huge regional infrastructural development deals. ${ }^{21}$ Together this is potentially triggering or setting off a security dilemma among external states against a backdrop of increasingly militarised competition.

Finally, South Africa's interest in continued counter-piracy is designed to signify to other countries that it possesses both the aspirations and capabilities to act as a regional leader or focal point in the provision of maritime security at national, regional and international level.

This is consistent with long-observed South African strategic cultural views about the region. It is also an outcome of perception of an indivisible link between South Africa's own economic functioning and security and that of its neighbours and partners in the region. In 2013, the Minister of Defence, Nosiviwe Mapisa-Nqakula, clearly expressed South Africa's logic for this approach, stating, "there is a legitimate causal connection between [1] combating piracy and [2] rendering Africa in general and the SADC region in particular economically viable and economically stable", ${ }^{22}$ This is important regarding the resilience of the Southern African system, which is not assured in the case of disruption. Concerns over fragility, therefore, have characterised the macroeconomic structure of most Southern African states, especially South Africa, for some time now.

The risk of the region being perceived, once again, as a vacuum in which external powers could posit themselves as necessary and thereby pursue other interests has also been anathema to South African decision-makers. For instance, in 2013, the (then) 
Chief of Naval Staff RADM Higgs suggested, "it is much better for South Africa to play a meaningful role in our continent than to leave that open to people from outside the continent because we don't have the capability". ${ }^{23}$ Pallo Jordan, a former South African member of parliament (MP), when addressing parliament warned, "Africa cannot afford to outsource the security of its coastline, ports and harbours to non-African powers". ${ }^{24}$ This statement was applauded by other MPs.

\section{SADC member state maritime leadership}

Southern African states have been important contributors to the international fight against piracy. They are now also important champions of maritime development by integrating the blue economy into their foreign policy goals and through promoting the role of regional organisations. ${ }^{25}$

Linked to the above, the fight against piracy has also presented opportunities for broader projects of revitalising and reconsidering African states' naval or maritime capacity. Tanzania and the Seychelles were especially hard hit - the Seychelles calculated it was losing huge amounts in tourist earnings. ${ }^{26}$

As Bueger has observed, piracy "has opened a window of opportunity to reorganise maritime security governance and build sustainable institutions". ${ }^{27}$ Malcolm and Murday observed "a willingness on the part of Seychelles and the broader region to institutionalise best practice and look at the transferability of responses for other maritime threats". 28

In 2018, President Danny Faure of the Seychelles was nominated to act as the AU's Blue Economy Champion. ${ }^{29}$ Several African states, including SADC member states such as South Africa, but especially the Seychelles and Mauritius, have developed national ocean or blue economy strategies and institutional mechanisms. The Seychelles recently launched its 'Blue Economy Strategic Framework and Roadmap', in collaboration with the Commonwealth. ${ }^{30}$ In particular, the Seychelles is described as "a major facilitator as well as policy entrepreneur and advocate for maritime security and the sustainable development of the oceans". ${ }^{31}$ The example and leadership the small island states have demonstrated are also disproportionate to their available resources and size. ${ }^{32}$ Mozambique also convened a blue economy conference in Maputo in 2019. ${ }^{33}$

\section{The SADC Standing Maritime Committee}

In the Standing Maritime Committee (SMC) of the SADC, member states of the Southern Africa region possess arguably one of the longest-lasting and consistently convened institutions dedicated to enhancing their common maritime security. The SMC has been the key forum for the SADC's unique mix of Atlantic Ocean, Indian Ocean and inland states to discuss and determine their recommendations for appropriate regional responses to maritime insecurity. It has also received high-level recognition - in 2012, the UN Secretary-General singled out the SMC in his annual report on the state of Somali piracy, expressing the belief that "[the] SADC could manage local threats from piracy in the Southern Indian Ocean region if it could develop maritime resources". ${ }^{34}$ 
The SMC was established as a sub-sub-committee to the Inter-State Defence and Security Committee (ISDSC), after a seminar held in Gaborone in March 1995. The primary role of the SMC is to recommend actions that are reported to the Defence Sub-Committee (DSC) and then to the ISDSC, in turn, an advisory body of the SADC organ. ${ }^{35}$ The SMC is therefore structurally marginally within the overall SADC security architecture (a sub-sub-sub-committee).

The SMC has met on an annual basis with a small secretariat located within the South African Navy. Chairship and hosting are shared and are rotated on an annual basis, although the four island states have yet to chair or host an SMC. As chairing is rotated on a yearly basis, this leaves little time for pursuing goals and lacking continuity and legacy.

The pattern of most member state attendance has fluctuated between regional engagement and disengagement. This can be attributed to their domestic circumstances in the case of political instability, a lack of dedicated resources in their budgets for participating, or absence, as in the case of the Seychelles withdrawing from the 2004-2008 meeting and Madagascar being suspended from 2009-2014. In addition, the membership of the Comoros only dates from 2017. The variation in attendance and the fact that many states did not send apologies has concerned both the SMC and its parent committees.

Chairing and hosting have also encountered significant obstacles. South Africa chaired for a lengthy initial period after inauguration of the SMC until it was deemed to be a consolidated and functioning institution.

Other notable indicators of sustained cooperative maritime security measures comprise attempts to improve interoperability through the convening of several ad hoc exercises and operations and the regional purchase of a common naval platform.

As noted earlier, the SADC has encouraged inland or lacustrine member states to improve their cooperation and involvement, for instance by convening riverine exercises. The outcome of successful initiatives could reasonably also be expected to increase capabilities pertaining to disaster response and management, peacekeeping missions and search and rescue. Although initial progress was sluggish owing to the lack of necessary capacity (including South Africa), the first exercise (Good Tidings) was held in Senga Bay, Malawi, from 19-30 September 2011. ${ }^{36}$ It was considered a huge success and provided a major learning experience. As of 2019, Namibia has established a naval base on Impalila Island in the Zambezi River, which is intended to allow for joint patrols with neighbouring Botswana and represents a good indicator of the improvement of relations with its neighbour since the sovereignty dispute over the Kasikili/Sedudu Island in the Chobe River. ${ }^{37}$

Member states within the region also participate with a broad range of external actors and other sub-regional organisations in multilateral exercises and fora aiming 
to enhance maritime security. Ongoing SADC naval efforts are now primarily located within or are dependent upon broader exercises and externally sponsored partnerships (such as the US Obangame Express and Cutlass Express). ${ }^{38}$ Moreover, as stated in the SADC SMC minutes, and while riverine exercises have taken place, there is cause for concern that independent SADC exercises might cease altogether. ${ }^{39}$

A long-held South African ambition was to facilitate the regional adoption of a common SADC offshore patrol vessel (OPV). ${ }^{40}$ This was expected to improve interoperability between SADC navies while boosting naval manufacturing in the region and reducing dependency on external partners. Interoperability is a common objective of the tasks and recommendations of the SMC, which has attempted to address them through training, planning and exercises. These OPVs were ideally intended to be suited to local sea conditions, affordable and tailored to the region's maritime security requirements.

South Africa expected to play a pivotal role, as the vessels were likely to have been constructed in South Africa. Not only was there little palpable interest; the SADC OPV project was seriously set back and unlikely ever to recover, by Mozambican purchases of vessels with secret loans whose discovery also had a devastating effect on the economy of that country. ${ }^{41}$ Other countries, such as Namibia, have also preferred to purchase vessels and conduct training with other long-term strategic partners, notably Brazil. ${ }^{42}$

There is also limited SADC maritime engagement in the Atlantic Ocean. Fellow SADC states - the DRC, Angola and Namibia - have not requested South African assistance with protection through counter-piracy patrolling. Joint exercises have seldom been both planned and successfully executed without external support, barring Exercise Golfinho (Dolphin) in $2009 .{ }^{43}$ The phenomenon of West African piracy has also tended to spread westward, rather than south, from Nigerian waters when displaced by counter-piracy operations. ${ }^{44}$ This points to the issue of member state orientation and agency. While Angola is an important SMC participant, it remains far more focused on West African and Gulf of Guinea-focused maritime security issues than on those of Southern Africa.

\section{SADC's strategic response to Somali piracy}

With the growth of the threat of Somali piracy, many SADC member states were forced to confront a serious external threat to their ultimate economic functioning and well-being.

The SADC SMC and chiefs of navy have been quick to note the importance of prompt and strategic action. At the $15^{\text {th }} \mathrm{SMC}$, two months after the 2009 Sirte AU Summit, Tanzania presented a paper on piracy, and Vice-Admiral Refiloe Mudimu, then Chief of the South African Navy, called for the development of an integrated SADC strategy. At the time, it was presumed that this strategy would entail how to overcome the challenges of the limited resources of most SADC navies and ways to use their aggregated strength to face and overcome maritime security challenges. ${ }^{45}$ 
Some SADC member states, such as the Seychelles and Mauritius, did not wait for the SADC to recommend how best to facilitate a coordinated, regional response to the threat of piracy. The Seychelles hosted a ministerial conference on piracy in May 2010, and an international symposium and a technical workshop in July 2010 to develop a suitable action plan for the region. Mauritius kept this momentum for a regional response by convening a second regional ministerial conference on piracy in October 2010, at which the Eastern and Southern Africa-Indian Ocean (ESA-IO) Regional Strategy and Regional Plan of Action was adopted. ${ }^{46}$ It can be seen that these events were anchored by appeals for stronger regional cooperation, but resulted from either unilateral or multilateral interests that did not prioritise a SADC regional response.

Despite participating in the meetings, the SADC did not openly endorse their outcomes or that it should expand its institutional engagement with this ESA-IO process. Neither event appeared in the Communique of the $30^{\text {th }}$ Ordinary Summit of the SADC Heads of State and Government in Windhoek, Namibia in August 2010. ${ }^{47}$ The 2010 Summit emphasised instead the importance of a regional counter-piracy response, noting how piracy seriously threatened the economic security of the Seychelles, Mauritius and Tanzania. The $30^{\text {th }}$ Ordinary Summit also mandated the SADC Secretariat to "send a team of technical experts to establish the extent of the problem and recommend appropriate measures". ${ }^{48}$

This focus on counter-piracy was quite common, as other regionalist plans and projects launched at the time, such as the Djibouti Code of Conduct, took a similarly narrow focus. ${ }^{49}$ It also soon appeared to be a prudent decision, as three unprecedented piracy attacks took place within the Mozambique Channel. In relatively quick succession, Somali pirates attacked the MV MSC Panama on 10 December 2010, the FV Shiuh FU No 1 on 25 December 2010, swiftly followed by the hijacking of the Vega 5 on 27 December $2010 .^{50}$

The 2011 SMC, which met in Swakopmund, Namibia from 23-25 February 2011, decided that the strategic working group, consisting of representatives from Angola, Botswana, Mozambique, Namibia, South Africa, Tanzania and Zambia, had to be convened later that year in South Africa to compile a draft SADC Maritime Strategy. This would be submitted to the 2012 SMC.

However, SADC later decided to convene an extraordinary meeting of defence ministers in Pretoria in July 2011 to develop and endorse a regional anti-piracy strategy further. The resulting strategy was adopted by SADC heads of state at the $31^{\text {st }}$ SADC Summit in August 2011 in Luanda, Angola.

The attacks in the Mozambique Channel in December had clearly struck a 'raw nerve', according to the (then) South African Defence Minister, Lindiwe Sisulu. ${ }^{51}$ This also tapped into a pervasive sense of pessimism that characterised much of the thinking in 2010 and 2011 on the prospects of reducing the threat of piracy. For instance, earlier in January 2011, Jack Lang, the UN special adviser on legal issues related to piracy off the coast of Somalia, suggested to the UN Security Council, "the pirates appear to be winning". 52 
The fast production of an MSS can also be explained by examining several other important contextual factors. Firstly, although warnings had been raised and discussed well before 2010, the attacks shattered the sense of security based on the presumption that Southern Africa's geographical remoteness from the strategic centre of gravity of Somali piracy in the Gulf of Aden was unlikely to be breached. A further assumption that the difficulties for pirates of reaching and operating in Southern African waters were considered too risky was also no longer valid..$^{53}$

The sense of intense vulnerability was likely buttressed by the fact that the Mozambique Channel fell outside of the HRA - a fundamental instrument in the fight against piracy that had stopped short of incorporating the Mozambique Channel. ${ }^{54}$ The HRA was used by insurance companies to demarcate the area in which special premiums would need to be paid when transiting. These additional costs threatened the economic functioning of many shipping companies and could decrease the revenues of regional ports if ships decided that this route was too prohibitive in cost and risk. Sisulu would go on to point out that the 'shoots of recovery' were appearing after the economic crisis of 2008, implying that the South African economy remained fragile and lacked the resilience to withstand further economic shocks or increased costs from disruptions to shipping. ${ }^{55}$ Moreover, the HRA had recently been extended to its furthest point and any entrenchment of piracy in the region or threatening the Cape of Good Hope sea route could result in it being extended again. This would create a number of economic difficulties for countries in the region, particularly South Africa, whose ports still handle the majority of regional trade.

The deployment of the South African Navy (SAN) to the region not only meant there were robust response capabilities in case of further piracy attacks. It could usefully provide also deterrence, for instance in demonstrating to littoral communities that piracy could not be carried out with impunity and that there was a great deal of risk involved with undertaking piracy in Southern Africa. ${ }^{56}$ As was noted in the earlier section on geopolitics, it was also likely intended to signify to the rest of the world that South Africa was the leading provider of maritime security in Southern Africa. This was imperative in the light of the recent discoveries of considerable amounts of gas in the EEZs of Tanzania and Mozambique, making the region the locus for a growing number of state and non-state counter-piracy actors. Moreover, these counter-piracy actor policies and identities might be incompatible with those of South Africa, as well as likely possessing resources and capabilities (and therefore incentives for partnerships) that might surpass South Africa's own.

\section{The difficulties of implementation}

The SMC acknowledged that the SADC MSS Action Plan was "drafted in a rush as a quick response to possible imminent maritime threats during that period". ${ }^{57}$ Analysts also agreed that the implementation of the MSS reflected South Africa's regional preoccupations, interests and aspirations. ${ }^{58}$ The tight timeline resulted in limited wider public debate and impeded consensus on an appropriate regional response. It could be argued, though, that the intention to revise the strategy or provide an updated maritime 
strategy was expressed by Lindiwe Sisulu in 2012 during an address to the Indian Ocean Naval Symposium. In reference to the Southern African region, she suggested, "any articulation of Regional Security Strategies, will need to be addressed holistically, with solutions addressing the full spectrum, including legislation and policy frameworks, matters of capacitation and more operational plans". ${ }^{59}$

Analysis of the SMC minutes since the MSS was adopted in 2011, identified key themes surrounding the requirements for the implementation of the MSS:

- establishment of Maritime Domain Awareness Centres (MDAC);

- funding sources for SADC MSS;

- appointment of an MSS representative at SADC headquarters;

- marketing of SADC MSS; and

- legislation in respect of reporting vessels entering SADC maritime zones. ${ }^{60}$

Unfortunately, the language and decisions of the SMC minutes regarding these themes have not changed since 2011, demonstrating there has been little discernible progress and therefore minimal buy-in from SADC member states.

Indeed, Operation Copper arguably suffered a serious setback when an 'operational pause' was declared from 5 September 2012 to 25 January $2013 .{ }^{61}$ According to the South African Department of Defence, the operational pause was declared to give Tanzania time to determine how it would contribute. However, the pause coincided with what turned out to be the last surge in Somali piracy. This meant there was no immediate capability in the region to counter any piratical acts, despite occurring not long after the only reported counter-piracy action involving Operation Copper, as well as the signing of the trilateral memorandum of understanding $(\mathrm{MoU})$ earlier that year. ${ }^{62}$

With the benefit of hindsight, it can clearly be observed that the number of reported Somali piracy incidents was already declining to ever-lower levels; yet, this trend could not have been identified at the time. Moreover, 75 incidents attributable to Somali pirates were still recorded by the International Maritime Bureau (IMB) during the pause, demonstrating that they still posed a considerable risk. ${ }^{63}$ In a further blow to the chances of consolidating or expanding the operation into a broader regional or multilateral initiative, Tanzania decided to withdraw from the agreement in $2013 .{ }^{64}$

South Africa has provided the majority of assets involved in the patrols since the operation resumed, deploying all available ocean-going naval capacity, comprising four valour-class frigates (which have shared patrol duties with the SAN's three recommissioned OPVs), the two operational submarines, the combat support vessel (the SAS Drakensburg), and the hydrographic vessel (the SAS Protea). In 2015, Operation Copper ceased routine air and maritime surveillance patrol and became an intelligence-driven operation instead. Naval assets are still deployed to the region by presidential directive, but now only for approximately a quarter of the year. Moreover, the South African 
Air Force (SAAF) no longer operates from Pemba, and its available maritime patrol aircraft in South Africa are unlikely to fly again. Furthermore, replacement aircraft have not been ordered thus far, leaving South Africa - and by extension the region - bereft of these crucially important maritime security assets. ${ }^{65}$

South Africa has persisted with Operation Copper but continues to focus on preparing the SAN for counter-piracy and/or presence patrols. The deployment is re-authorised and funded on an annual basis by presidential directive and generally framed as an anti-piracy deployment. How long the operation will continue beyond 2020 cannot be confirmed at present, as Mozambique has not indicated whether it wishes the operation to cease, as per one of the conditions of the MoU. However, the potential capacity problems facing the SAN in 2022 if, as forecast, it loses both its frigate and submarine capability, could bring the curtain down on Operation Copper. ${ }^{66}$

The requirement for a suitable regional instrument capable of coordinating inter-state policies and deployments has also grown since 2011 in relation to other maritime crimes. The Southern African maritime domain is now the site of an increasing number of sophisticated transnational crimes and criminal networks involved in drug trafficking, human trafficking, arms smuggling and illegal fishing.

Heroin trafficking into Tanzania, Mozambique and South Africa through the 'Southern Route' has emerged as a major concern. ${ }^{67}$ These responses are not, however, the result of SADC initiatives but are rather regional responses facilitated by the United Nations Office for Drugs and Crime (UNODC). Not only could a failure to deal effectively with drug trafficking lead to public health and human security concerns, but it could have serious political consequences, such as the degradation of state institutions as a result of increased corruption. The emergence of this route can be taken as an indicator of successful law enforcement practices in traditional sites and routes. As was previously observed with piracy in both East and West Africa, maritime criminal actors and networks possess the ability to build new routes and areas of operation even when displaced from traditional routes.

\section{The role of the SMC in revising the SADC MSS in 2019}

Meanwhile, the SMC acknowledged in 2016 the inapplicability of the MSS for the present circumstances and claimed, "there is a need for it [the SADC MSS] to be reviewed and re-evaluated to meet the current and possible future maritime threats". ${ }^{68}$

Progress on this review and re-evaluation has been relatively slow in contrast to the swift drafting process of 2011, which resulted in the MSS under whose auspices Operation Copper continues to be deployed. The $26^{\text {th }}$ meeting of the SADC Defence Sub-Committee in Angola in May 2018 directed the SADC Secretariat to develop a draft concept paper on revising the SADC MSS. ${ }^{69}$ The recommendations of this paper were then presented to the SADC MSS Review Work Session in South Africa at the 2019 SMC. The SMC member states in attendance accepted the proposed changes to the SADC MSS and recommended that a SADC MSS Review Work Group be established to prepare and submit a draft SADC MSS for review and adoption. 
The resultant SADC MSS Review Work Group met in Pretoria from 23-25 July 2019 to draft an integrated maritime security strategy. ${ }^{70}$ This was chaired by the DRC and comprised delegates from the SMC and two DSC sub-committees - the Defence Intelligence Standing Committee (DISC) and the Defence Legal Work Group (DLWG). Significant changes from past SMC meetings were the fact that the DRC chaired an SMC initiative for the first time and the presence of representatives from the Seychelles and Mauritius. Whether this is an indicator of future participation and buy-in for participation in the SMC meetings and the revision of the SADC strategy remains to be seen. The revised SADC MSS is due to be presented at the $26^{\text {th }} \mathrm{SMC}$ in the DRC in 2020, after which some of these queries can be clarified. These member states already prioritise substantial initiatives, such as promoting blue economy policies, the chairing and support of the Contact Group on Piracy off the Coast of Somalia (CGPCS) and the recent convening of a second Ministerial Conference on Maritime Security in Mauritius. ${ }^{71}$ Much will depend on whether the perceptions and evaluations of the SADC as an institution change among member states. This is a process that the SADC and the SMC need to encourage by facilitating continual communication between member states in the revision of the MSS and beyond.

\section{Conclusion}

This article discussed the role that regionalism plays in the foreign policies of SADC member states towards the organisation regarding maritime security. This is not an exhaustive document and while it draws from a medley of schools of thought, has not provided an explication based on constructivist theory regarding culture and identity owing to the limited space available for the article.

Many SADC member states have embraced regionalism in their policies and preparations to address maritime insecurity issues. Despite a heavy emphasis on a regional approach to maritime solutions, few SADC member states prioritise strengthening SADC maritime institutions or implementing the MSS to accomplish these objectives. This could be changing, although it has taken time. An encouraging outcome of the $39^{\text {th }}$ Ordinary Summit of the Heads of State and Government of SADC in Dar es Salaam, Tanzania in August 2019 was that it stated it now possessed a better understanding of "the gravity of maritime security threats, such as piracy, maritime terrorism, drug trafficking and illegal carrying and trafficking of weapons and ammunition." The Summit also decided to "jointly address them as part of a SADC Maritime Security Strategy". ${ }^{72}$

Whether these are signs that the strategic value of the SADC is changing or that the SADC could become a platform for strategic convergence is too early to tell. The article noted there a few optimistic indicators among previously absent member states such as the Seychelles and Mauritius, of a greater interest in engaging with SADC maritime initiatives. The active role of the DRC in chairing and hosting SMC workshops and meetings is also a significant milestone. Much will now depend on how the perceptions and evaluations of the SADC as an institution are changed among member states, a process that the SADC and the SMC should encourage by facilitating continual communication among member states in the process of revising the MSS and its implementation. 


\section{ENDNOTES}

${ }^{1} \mathrm{~N}$ Klein. Maritime security and the law of the sea. Oxford: Oxford University Press, 2011, 9.

${ }^{2}$ C Bueger. "What is maritime security?" Marine Policy 53. 2015. 159-164.

${ }^{3}$ A Vogel. "Navies versus coast guards: Defining the roles of African maritime security forces". Africa Center for Strategic Studies Security Brief 2. 2009. 1-6.

${ }^{4} \mathrm{~S}$ Bateman. "Solving the 'wicked problems' of maritime security: Are regional fo rums up to the task?" Contemporary Southeast Asia 33/1. 2011. 1-28.

${ }^{5}$ PM Wambua. "Enhancing regional maritime cooperation in Africa: The planned end state". African Security Review 18/3. 2009. 51.

${ }^{6}$ I addressed the SADC MSS Review Workshop on 25 July 2019, delivering an over view of regional and continental maritime strategies and implementation processes and then providing a draft SADC revised strategy framework for the consideration of the Work Group.

${ }^{7}$ Four countries are Atlantic littorals: the Democratic Republic of Congo, Angola, Namibia and South Africa, while seven countries (again including South Africa) are located in, or adjacent to, the Indian Ocean: South Africa, Mozambique, Tanzania, Madagascar, the Comoros, Mauritius and the Seychelles.

${ }^{8}$ The Comoros, Madagascar, Mauritius and the Seychelles. The other two states Cape Verde and Sao Tome e Principe - are members of ECOWAS.

${ }^{9}$ As per the 2050 AIM Strategy, Africa's maritime domain includes "all areas and resources of, on, under, relating to, adjacent to, or bordering on an African sea, ocean, or African lakes, intra-coastal and inland navigable waterways, including all African maritime-related activities, infrastructure, cargo, vessels and other means of conveyance. It also includes the air above the African seas, oceans, lakes, intra-coastal and inland navigable waterways and to the oceans' electromagnetic spectrum as well". African Union. "2050 AIM Strategy". N.d. $<$ https://au.int/en/documents-38> Accessed on 18 August 2019.

${ }^{10}$ The conceptual and legal issues with this definition are noted, but their critical discussion lies outside the scope of this article. Suffice to say, the 2050 AIMS has been adopted and forms an integral point of departure and navigational tool for understanding the African maritime domain; $\mathrm{T}$ Walker. "Reviving the AU's maritime strategy". ISS Policy Brief 96. 2017. 1-8.

${ }^{11}$ Standing Maritime Committee of the ISDSC. "Minutes of the 14th meeting of the Standing Maritime Committee (SMC) of the Interstate Defence and Security Committee (ISDSC), Luanda, Angola, 25 to 29 August 2008". $<$ http://www.navy.mil.za/SMC/2008/Record\%20of\%2014th\%20SMC\%20 Meeting\%20(English).pdf $>$ Accessed on 14 September 2019.

${ }^{12} \mathrm{~J}$ van Wyk. "Defining the blue economy as a South African strategic priority: Toward a sustainable 10th province?" Journal of the Indian Ocean Region 11/2. 2015. 153-169. 
${ }^{13} \mathrm{~J}$ Childs. "Extraction in four dimensions: Time, space and the emerging geo(-) politics of deep-sea mining". Geopolitics 25/1. 2020. 189-213.

${ }^{14} \mathrm{KG}$ Sammler. "The rising politics of sea level: Demarcating territory in a vertically relative world". Territory, Politics, Governance 2019. 1-17.

${ }^{15}$ P Edmond, K Titeca \& E Kennes. "The DRC-Angola offshore oil dispute: How regime (in)security outweighs sovereign claims". Journal of Southern African Studies 45/5. 2019. 841-857.

${ }^{16}$ J Myall. "The Malawi-Tanzania boundary dispute". The Journal of Modern African Studies 11/4. 1973. 611-628; A Lalbahadur. "A stitch in time: Preventive diplomacy and the Lake Malawi dispute”. SAIIA Policy Insights 32. 2016. $1-10$.

${ }^{17} \mathrm{O}$ Bowcott. "UN court rejects UK's claim of sovereignty over Chagos Islands". The Guardian. 25 February 2019. <https://www.theguardian.com/world/2019/ feb/25/un-court-rejects-uk-claim-to-sovereignty-over-chagos-islands $>$ Accessed on 13 February 2020.

${ }^{18}$ See for instance T Potgieter \& R Pommerin (eds). Maritime security in southern African waters. Stellenbosch: SUN MeDIA, 2015; FA Kornegay. "South Africa and SADC in the Indian Ocean maritime security equation". Journal of the Indian Ocean Region 8/1. 2012. 71-89; P Brits \& M Nel. "A wakeup call for navies in the SADC region: Towards more effective maritime law enforcement". Acta Criminologica 29/2. 2016. 172-187; A Royeppen. "Rethinking challenges to SADC's Maritime Security Model". Institute for Global Dialogue/University of South Africa. N.d. < $\underline{\text { https://www.igd. }}$ org.za/11204-rethinking-challengesto-sadc-s-maritime-security-model> Accessed on 18 August 2019.

${ }^{19} \mathrm{C}$ Bueger. "Territory, authority, expertise: Global governance and the counter-piracy assemblage". European Journal of International Relations 24/3. 2018. 614-637.

${ }^{20}$ B Nhamire \& M Hill. "Mozambique's \$49 billion gas plan stokes anxiety in North". Bloomberg. July 23 2018. < https://www.bloomberg.com/news/articles/2018-07-22/mozambique-s-49-billion-gas-plan-stokes-anxiety-in-ruralnorth> Accessed on 13 February 2020.

${ }^{21}$ P Fabricius. "The resource curse comes to Mozambique". ISS Today. 9 June 2016. $<\underline{\text { https://issafrica.org/iss-today/the-resource-curse-comes-to-mozambique }>}$ Accessed on 13 February 2020.

${ }^{22}$ Parliamentary Monitoring Group (PMG). "Hansard: Debate on budget vote no. 22 Defence and Military Veterans”. National Assembly. 23 May 2013. $<\underline{\text { https:// }}$ pmg.org.za/hansard/18377/> Accessed on 6 May 2019.

${ }^{23}$ News24. "Navy short of ships". 22 August 2013. <https://www.news24.com/South Africa/Politics/Navy-short-of-ships-20130822> Accessed on 18 August 2019. 
${ }^{24}$ PMG. "Hansard: Resumption of debate on the President's State-of-the-NationAddress". National Assembly. 19 June 2014. <https://pmg.org.za/hansard/18552/> Accessed on 6 May 2019.

${ }^{25}$ JA Malcolm \& L Murday. “Small islands' understanding of maritime security: The cases of Mauritius and Seychelles". Journal of the Indian Ocean Region 13/2. 2017. 251.

${ }^{26}$ AFT Fernando. "An insight into piracy prosecutions in the Republic of Seychelles". Commonwealth Law Bulletin 41/2. 2015. 173-212; M Fuchs. "Seychelles economic growth hurt by piracy: Minister". Reuters. 18 April 2011. $<$ https://www.reuters.com/article/ozatp-seychelles-piracy-idAFJOE73H0F120110418> Accessed on 13 September 2019.

${ }^{27} \mathrm{C}$ Bueger. "Learning from piracy: Future challenges of maritime security governance". Global Affairs 1/1. 2015. 33-42.

${ }^{28}$ Malcolm \& Murday op. cit., p. 251.

${ }^{29}$ T Walker \& D Reva. "Harnessing Africa's blue economy”. ISS Today. 10 December 2018. <https://issafrica.org/iss-today/harnessing-africas-blue-economy> Accessed on 13 February 2020.

${ }^{30}$ The Commonwealth. "Roadmap to boost Seychelles' blue ocean economy". 11 October 2018. < https://thecommonwealth.org/Roadmap $\% 20$ to $\% 20$ boost $\% 20$ Seychelles $\% 20$ blue $\% 20$ ocean $\% 20$ economy $>$ Accessed on 26 September 2019.

${ }^{31} \mathrm{C}$ Bueger \& A Wivel. "How do small island states maximize influence? Creole diplomacy and the smart state foreign policy of the Seychelles". Journal of the Indian Ocean Region 14/2. 2018. 170.

32 Ibid., pp. 170-188.

${ }^{33}$ R Chevallier \& E Fuller. "East Africa: Marine-based 'blue economies' offer massive potential”. South African Institute for International Affairs. 23 May 2019. $<$ https://saiia.org.za/research/east-africa-marine-based-blue-economies-offer-massive-potential/> Accessed on 13 February 2020.

${ }^{34}$ UN Security Council. "Report of the Secretary-General pursuant to Security Council resolution 2020 (2011)". 22 October 2012. < http://www.securitycouncilreport.org/atf/cf/\%7B65BFCF9B-6D27-4E9C-8CD3CF6E4FF96FF9\%7D/s_2012_783.pdf>Accessed on 13 February 2020.

${ }^{35}$ Southern African Development Community. "Organ on Politics Defense and Security Affairs". N.d. <https://www.sadc.int/sadc-secretariat/directorates/ office-executive-secretary/organ-politics-defense-and-security/ $>$ Accessed on 13 February 2020.

${ }^{36}$ defenceWeb. "Good tidings on Lake Malawi”. 14 October 2011. $<$ https://www.defenceweb.co.za/sea/sea-sea/good-tidings-on-lake-malawi/> Accessed on 13 February 2020.

${ }^{37}$ defenceWeb. "Namibia commissions new naval facility". 26 June 2019. <https://www.defenceweb.co.za/security/maritime-security/namibia-commissions-new-naval-facility/> Accessed on 3 July 2019. 
${ }^{38}$ US Navy. "Exercise Cutlass Express 2019 concludes". defenceWeb. 11 February

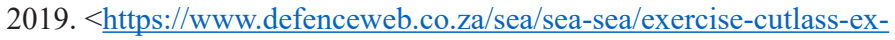
press-2019-concludes/> Accessed on 18 August 2019.

${ }^{39}$ Standing Maritime Committee of the ISDSC. "Minutes of the 24th meeting of the Standing Maritime Committee (SMC) of the Interstate Defence and Security Committee (ISDSC) held in Gaborone, Botswana from 10 to 11 May 2018". $<$ http://www.navy.mil.za/SMC/2018 documentation.htm> Accessed on 14 September 2019

${ }^{40} \mathrm{~K}$ Campbell. "South African Navy mulls future requirements as fleet remains active". Creamer Media's Engineering News. 4 October 2013. $<\underline{\text { http: } / / w w w . ~}$ engineeringnews.co.za/article/south-african-navy-mulls-future-requirements-as-fleet-remains-active-2013-10-04-1> Accessed on 13 February 2020.

${ }^{41}$ L Louw-Vaudran. "What does ensuring SADC's maritime security mean for South Africa?” ISS Today. 16 April 2014. < $\underline{\text { https://issafrica.org/iss-today/ }}$ what-does-ensuring-sadcs-maritime-security-mean-for-south-africa $>$ Accessed on 13 February 2020; J Hanlon. "Following the donor-designed path to Mozambique's US\$2.2 billion secret debt deal”. Third World Quarterly 38/3. 2017. 753-770.

${ }^{42}$ P Seabra. "Defence cooperation between Brazil and Namibia: Enduring ties across the South Atlantic". South African Journal of International Affairs 23/1. 2016. 89-106.

${ }^{43} \mathrm{H}$ Boshoff. "Exercise Golfinho an example for other continental brigades". ISS Today. 13 October 2009. <https://issafrica.org/iss-today/exercise-golfinho-an-example-for-other-continental-brigades $>$ Accessed on 13 February 2020.

${ }^{44}$ L Otto. "Westward ho! The evolution of maritime piracy in Nigeria". Portuguese Journal of Social Science 13/3. 2014. 313-329.

${ }^{45}$ Standing Maritime Committee of the ISDSC. "15th meeting of the Standing Maritime Committee (SMC) of the Interstate Defence and Security Committee (ISDSC): Victoria Falls, Zimbabwe: 17 to 21 August 2009”. < $\underline{\text { http:// }}$ www.navy.mil.za/SMC/2009 documentation.htm> Accessed on 13 February 2020.

${ }^{46}$ Malcolm \& Murday op. cit.

${ }^{47}$ Republic of Namibia. "Communiqué of the 30th Jubilee Summit of SADC Heads of State and Government”. 17 August 2010. <https://www.sadc.int/ files/3613/5341/5517/SADC Jubillee Summit Communique.pdf.pdf $>$ Accessed on 6 August 2019.

48 Ibid.

${ }^{49}$ A Menzel. "Institutional adoption and maritime crime governance: the Djibouti Code of Conduct". Journal of the Indian Ocean Region 14/2. 2018. 152-169. 
${ }^{50}$ Economist Intelligence Unit. "Naval patrols are to counter piracy in Mozambican waters". The Economist. 4 March 2011. <http://country.eiu. com/article.aspx?articleid $=1657858350 \&$ Country=Mozambique \& topic $=$ Politics\&subtopic $=$ Recent + developments\&subsubtop-

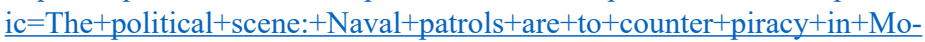
zambican+waters $>$ Accessed on 18 August 2019.

${ }^{51}$ South African Government. “Address by LN Sisulu, MP, Minister of Defence and Military Veterans at the SADC Extraordinary Meeting on Regional Anti-Piracy Strategy". 25 July 2011. < $\underline{\text { https://www.gov.za/address-1-n-si- }}$ sulu-mp-minister-defence-and-military-veterans-sadc-extraordinary-meeting-regional> Accessed on 18 August 2019; DP Baker. "The South African Navy and African maritime security". Naval War College Review 65/2. 2012. 145-166.

${ }^{52}$ United Nations, Department of Public Information. "In race between pirates and international community, pirates clearly winning, Secretary-General's top legal adviser on piracy warns Security Council”. 25 January 2011. $<\underline{\text { https:// }}$ www.un.org/press/en/2011/sc10164.doc.htm> Accessed on 18 August 2019.

${ }^{53} \mathrm{H}$ Fouché. "Somali pirates take to the high seas: Expediency or long-term pirate strategy?" Scientia Militaria 37/2. 2009. 67-81.

${ }^{54} \mathrm{D}$ Reva. "Can we afford to drop the guard against piracy?” ISS Today. 28 June 2019. $<$ https://issafrica.org/iss-today/can-we-afford-to-drop-the-guardagainst-piracy $>$ Accessed on 14 September 2019.

${ }^{55}$ South African Government op. cit.

${ }^{56}$ JPB Coelho. African approaches to maritime security: Southern Africa. Maputo: Friedrich Ebert Stiftung, 2013.

${ }^{57}$ Standing Maritime Committee of the ISDSC. "Minutes of the 22nd meeting of the Standing Maritime Committee (SMC) of the Interstate Defence and Security Committee (ISDSC): Swakopmund, Namibia: 24-26 February 2016". <http://www.navy.mil.za/SMC/2016 documentation.htm $>$ Accessed on 14 September 2019.

${ }^{58}$ Coelho op. cit.; M Blaine \& J Sinovich. "Ensuring the SADC maritime interest through good order at sea". In F Vreÿ \& T Mandrup (eds). Towards good order at sea. Stellenbosch: SUN MeDIA, 2015, 221.

${ }^{59}$ South African Government. "Keynote address by LN Sisulu, MP, Minister of Defence and Military Veterans at the occasion of the Indian Ocean Naval Symposium held in Cape Town". 11 April 2012. <http://www.dod.mil.za/ ministry/media statements/2012/apr/IndianOceanNavalSymposium.htm> Accessed on 26 September 2019.

${ }^{60}$ Standing Maritime Committee of the ISDSC, Minutes of the 24th meeting op. cit.

${ }^{61}$ South African Department of Defence and Military Veterans. Department of Defence and Military Veterans annual report FY2012/13. Cape Town: Formeset Printers, 2013, 24. 
${ }^{62}$ defenceWeb. "Sisulu signs maritime security MoU with Tanzania and Mozambique”. 8 February 2012. < https://www.defenceweb.co.za/sea/seasea/sisulu-signs-maritime-security-mou-with-tanzania-and-mozambique/> Accessed on 13 February 2020.

${ }^{63}$ International Maritime Bureau. "Piracy falls in 2012, but seas off East and West Africa remain dangerous, says IMB". Commercial Crime Services. 16 January 2013. <https://www.icc-ccs.org/news/836-piracy-falls-in-2012-butseas-off-east-and-west-africa-remain-dangerous-says-imb $>$ Accessed on 13 February 2020.

${ }^{64}$ G Martin. "Operation Copper now only with SA and Mozambique". defenceWeb. 20 March 2014. <https:/www.defenceweb.co.za/security/maritime-security/ operation-copper-now-only-with-sa-and-mozambique/> Accessed on 13 February 2020.

${ }^{65}$ defenceWeb. "No new SAAF aircraft acquisition until budget changes". 29 October 2019. <https://www.defenceweb.co.za/aerospace/aerospace-aerospace/no-new-saaf-aircraft-acquisition-until-budget-changes/> Accessed on 13 February 2020.

${ }^{66}$ G Davis. "SA Air Force, Navy financials in 'dire straits"”. EWN. 12 September 2019. <https://ewn.co.za/2019/09/12/sa-air-force-navy-financials-in-direstraits $>$ Accessed on 13 February 2020.

${ }^{67}$ Department of International Relations and Cooperation. "Statement by the Deputy Director-General Global Governance and Continental Agenda of South Africa, Ambassador Mxolisi Nkosi, during the United Nations Security Council Debate on 'Transnational Organised Crime at Sea as a Threat to International Peace and Security"”. 5 February 2019. < $\underline{\text { http://www.dirco.gov. }}$ za/docs/speeches/2019/nkos0205.htm $>$ Accessed on 13 February 2020.

${ }^{68}$ Standing Maritime Committee of the ISDSC, Minutes of the 22nd meeting op. cit.

${ }^{69}$ In contrast to the past, there was (at the time) an officer in the SADC Secretariat planning element who could be tasked to draft this concept paper.

${ }^{70}$ defenceWeb. "SADC successfully drafts Integrated Maritime Security Strategy". 21 August 2019. < https://www.defenceweb.co.za/security/maritime-security/ sadc-successfully-drafts-integrated-maritime-security-strategy/> Accessed on 22 August 2019.

${ }^{71}$ Department of Foreign Affairs, The Republic of the Seychelles. "Seychelles participates in the 2nd Ministerial Conference on Maritime Security in Mauritius". 20 June 2019. <http://www.mfa.gov.sc/static.php?content

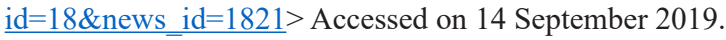

${ }^{72}$ United Republic of Tanzania. "Communiqué of the 39th Summit of SADC Heads of State and Government, Julius Nyerere International Convention Centre, Dar es Salaam, United Republic of Tanzania”. 18 August 2019. $<\underline{\text { https:// }}$ www.sadc.int/files/1915/6614/8772/Communique of the 39th_SADC Summit-English.pdf $>$ Accessed on 16 September 2019. 